УДК $821.161 .2+355.12$

ТОМЧУК О.А.

\title{
ВАГОМИЙ ВНЕСОК ВОЛОНТЕРІВ У ВИСВІТЛЕННІ ІСТОРІЇ СУЧАСНОЇ РОСІЙСЬКО-УКРАЇНСЬКОЇ ВІЙНИ
}

У вогняному кільці. Оборона Луганського аеропорту / Сергій Глотов, Анастасія Глотова, Анастасія Воронова; Юрій Руденко, Дмитро Путята; худож.-оформлювач В. М. Карасик. - Харків: Фоліо, 2018. -540 с.: іл.-(Хроніка)

На сьогодні тема російсько-української війни $є$ найбільш затребуваною в українському публічному просторі. Команда українських волонтерів, очолювана керівником благодійного фонду «Народна підтримка воїнів АТО» Сергієм Глотовим, провела унікальну науково-дослідну роботу 3 історії сучасної російсько-української війни. Вона протягом 2016 - 2018 років провела інтерв'ю та записала спогади близько 140 учасників та очевидців тих подій - військових, волонтерів, місцевих мешканців, працівників міліції та аеропорту, медиків. Інтерв'ю з ними стали основою документальної хроніки, яка побачила світ влітку 2018 p.

Благодійний фонд «Народна підтримка воїнів АТО» (www.facebook.com/VoinamATO) зареєстровано 26.10.2015 p. До того часу (починаючи 3 травня 2014 р.) волонтерський актив фонду діяв у рамках громадської ініціативи, що об'єднувала декілька волонтерських груп. Основним напрямом діяльності організації $є$ допомога військовим Збройних Сил України (далі - ЗСУ), та добровольчих батальйонів у зоні проведення ATO. Додатковими напрямами роботи є гуманітарна допомога жителям прифронтових територій, зокрема дітям, виготовлення патріотичної поліграфічної продукції, інформаційно-просвітницька діяльність. У роботі фонду наразі задіяно понад 60 волонтерів зі Львова та інших міст України.

Томчук Олександр Анатолійович, ад’юнкт науково-дослідної лабораторії (військово-історичних досліджень) Наукового центру Сухопутних військ Національної академії сухопутних військ імені гетьмана Петра Сагайдачного, м. Львів.

(C) Томчук O.A. 
Книга, яку підготували волонтери, містить також коментарі військових дослідників, офіцерів та експертів, а також перелік загиблих бійців із різних підрозділів. Доповнюють історичні свідчення рідкісні фотографії, зроблені оборонцями та волонтерами, а також картосхеми, що ілюструють основні бойові операції. Хроніка охоплює хронологічний період, що передував окупації Луганська та прилеглих територій (зима-весна 2014 р.), та безпосередньо оборону міжнародного аеропорту (квітень початок вересня 2014 р.).

Розповіді про перебування на Сході України й службу військовиків в умовах ведення бойових дій дозволяють доповнити розуміння подій, що відбувалися в державі. За деякий час наративи учасників оборони луганського аеропорту стануть у пригоді при формуванні офіційної пам'яті про збройний конфлікт, розпочатий агресією Російської Федерації проти України у 2014 році.

Вивчення «гарячих» подій, які $є$ популярними й емоційно небезпечними для сприйняття, ставлять дослідників перед дилемою суспільного осмислення й дотримання терміну давності в подачі матеріалу, водночас зобов'язують фіксувати спогади очевидців подій для подальшого використання. Це доволі нова техніка для українських фахівців-істориків, оскільки до цього часу всі тематичні блоки опитувань стосувались подій, які оповідачі пережили раніше, осмислили їх, приховали й стерли зі своєї життєвої історії наболіле та невигідне під дією офіційної версії трактування історичних подій чи усталених стереотипів. Натомість у розмові 3 учасниками подій $є$ місце обдуманим сюжетам і міркуванням, які слугують елементами конструювання самого себе як героя, жертви або ж спостерігача - вже на власний вибір. Тому трапляється недовіра у деяких дослідників до усних джерел, звинувачення у суб'єктивному трактуванні пережитого як єдино правильного.

Усна історія - це досить поширений сьогодні напрям соціально-гуманітарних досліджень, який надзвичайно динамічно розвивається і головним предметом якого є суб'єктивний досвід окремої людини. Його основний метод дослідження - інтерв'ю, i в цьому він близький за своєю специфікою до інших наук: соціології, психології, етнографії, етнології, культурної 
антропології. Хоча складовою поняття $є$ слово «історія», все ж усна історія - це не нова галузь історичної науки, а нова методика - спосіб залучення до аналізу нової категорії джерел, поряд із писемними джерелами та матеріальними об'єктами. На сьогодні консенсусу щодо остаточної дефініції усної історії не досягнуто, але більшість науковців наголошують на міждисциплінарності цього напряму.

Автори-упорядники зібрали дуже великий архів - близько 5 тисяч сторінок спогадів, з яких 580 увійшли у видання. Десятки волонтерів із різних міст України збирали інтерв'ю та розшифровували десятки годин диктофонних записів. Долучилися до цієї важливої справи й військовослужбовці Національної академії сухопутних військ імені гетьмана Петра Сагайдачного, у тому числі й автор даної рецензії. Розташована поряд з Академією 80-а ОАЕМБр разом із іншими підрозділами героїчно обороняла аеропорт («Восьмидесятка» первой заходила, «восьмидесятка» последней и уходила...» - вірно зазначає солдат 3 позивним «Сухий», стор.451). «Коли ми вийшли з Луганського аеропорту, згадує командир «восьмидесятки», на той час полковник Андрій Ковальчук, - нас не вибили - ми просто залишили. Бо необхідності його тримати як стратегічну точку, точку опори далі не було. [...] Ми виходили - то він горів, горів повністю...(стор. 446).

Були опитані десятки військовослужбовців цієї частини, від рядових до керівного складу. Такий великий архів дозволяє зробити припущення, що випуски спогадів учасників війни на Сході України будуть продовжені. Унікальність дослідження в ділянці усної історії полягає в тому, що дослідник може не лише інтерпретувати певні джерела, але й залучений у процес їхнього створення. Отож, чи не найважливішою ланкою у цьому процесі $\epsilon$ інтерв'ювання.

Добре у книзі висвітлено зародження i діяльність на Луганщині волонтерського руху у допомогу Збройним Силам України. Це малодосліджена сторінка історії війни на Сході України. Частина Луганської області перебуває під російською окупацією, й називати прізвища волонтерів означало би наражати їх на небезпеку. Однак у хроніці переконливо висвітлена масова підтримка населенням цього регіону ЗС України. 
Українським воїнам-оборонцям аеропорту допомагали групи небайдужих луганчан, зокрема викладачі та студенти луганських вишів, священнослужителі й прості прихожани. Отець Володимир Безпалий, священик Свято-Троїцького кафедрального собору Української православної церкви Київського патріархату згадує: «Наша церква була єдиною в місті, де збирали допомогу для військових. Люди різне приносили - харчі, закрутки, теплий одяг, шкарпетки (бо холодно ще було), і гроші - хто що міг. Збирали це все, і владика приблизно раз на тиждень відвозив хлопцям. Ще до того, як завели бійців до аеропорту, - ми возили гуманітарну допомогу хлопцям на кордон, вони там стояли ще 3 березня. Владика казав, що будемо до останнього збирати i возити допомогу - хай хоч розстріляють»( стор.76).

Найбільша проблема, пригадують бійці, була 3 водою. Збирали та пили й дощову воду. Місцеві волонтери з Луганська, ризикуючи життям, намагалися привозити воду у пляшках. Серед тих, хто допомагав українським захисникам, були волонтери Сергій і Анастасія Глотови. Саме їм належала ідея видати книгу про оборону Луганського аеропорту.

Окрема частина книга присвячена репресіям i «полюванню» на волонтерів міста та області. Волонтерський рух на Сході України $\epsilon$ свідченням того, що значна частина населення Луганщини 3 нетерпінням очікує визволення від «російських обійм». Заключна частина хроніки має назву «Ми повернемося» $\mathrm{i}$ вселяє впевненість в остаточну перемогу над ворогом та звільнення окупованих територій.

Учасник оборони капітан Олег Гільжинський говорить в інтерв'ю: «Так хочеться повернутись туди. Проїхатись по тих дорогах, по яких під обстрілами їздили, прийти на ці руїни. I спочатку закропити їх кров’ю ворога, а пізніше, коли звільним цю землю, покласти квіти на це місце, де був термінал, запалити свічку. Устати на коліна, зняти шолом і помолитися за тих, хто там залишився назавжди. Я майже кожну ніч бачу уві сні ці бої. Мене ще ніколи нікуди так не тягнуло, як тягне в аеропорт...» (стор. 451).

Рецензована книга-хроніка містить також коментарі офіцерів і експертів про оборону Луганського аеропорту. На думку більшості, Луганський аеропорт як стратегічний об'єкт зіграв 
важливу роль у подальшому розвитку усієї ситуації на Донбасі. Луганські оборонці, як i оборонці Донецького аеропорту («кіборги»), продемонстрували незламність українського воїнства.

Автори книги зібрали відомості й надрукували список загиблих і зниклих безвісти українських військовослужбовців під час оборони Луганського аеропорту. Але не вдалось знайти повну інформацію про волонтерів і мирних жителів, які загинули в околицях Луганського аеропорту протягом березня-серпня 2014 року. Після Перемоги слід їх усіх згадати й, можливо, на місті колишнього аеропорту побудувати меморіал, як символ героїзму українських воїнів.

Події, які переживає народ України упродовж сучасної російсько-української війни, ще раз засвідчили, що проголошена у 1991 р. державна незалежність потребує постійного захисту, глибокого розуміння та оцінки того, що відбувається навколо нас. Саме тому на лекціях та семінарських заняттях курсантів, присвячених сьогоденню, особлива увага повинна приділятися ролі учасників бойових дій на Сході України та волонтерам. Необхідно акцентувати увагу на тому, що патріотизм в нинішній час проявляється не лише в безпосередній борні на Сході із зовнішнім ворогом, не тільки в надзвичайних ситуаціях, але $є$ звичайним станом повсякденного життя людини.

Рекомендуємо широко використовувати матеріали книгихроніки «У вогняному кільці. Оборона Луганського аеропорту» на заняттях 3 курсантами та військовослужбовцями. Усім, хто скеровується на російсько-український фронт, радимо прочитати цю книгу. Там вони знайдуть багато корисних, практичних порад щодо ведення бойових дій, облаштування побуту на передовій, ще раз переконаються у важливості дотримання дисципліни та відповідальності, що допоможуть врятувати життя у скрутні моменти війни.

Вважаємо, що дослідження у сфері усної історії серед учасників російсько-української війни повинні тривати й надалі. Такі дослідження сприяли би накопиченню, опрацюванню та уведенню у науковий обіг джерел усної історії; розробці тематичних курсів та навчальних програм для студентів вищих військових навчальних закладів. Слід розширяти та впорядкувати базу інтерв'юерів - учасників сучасної російсько-української війни і в наступні роки.

Надійшла до редколегії 15.09.2018 р. 